
1983:58:807-9

22 W'ells JL, James DK, Luxton R, Pennock CA. Maternal leucocite zinc deficiency at start of third trimester as a predictor of fetal growth retardation. Br.11ed f 1987:294:1054-6.

3 Simmer K, Thompson RPH. Maternal zinc and intrauterine growth retardation Clin Si 1 1985:68:395-9.

4 Paul AA, Southgate DAT, eds. McCance and Widdowson's the composition of

foods. th ed. London: HMSO, 1985. (MRC special report No 297 .)

25 Braddon FEM, Wadsworth MEJ, Davies JMC, Cripps HA Social and regional differences in food and alcohol consumption and their measurement in a national birth cohort. $f$ Epidemiol Communtzy Health 1988:42:341-9. inast G, Saling E. Effect of oral zinc application during pregnancy. (jonecol Obstet Invest 1986;21:117-23.

27 Hunt IF, Murphy NJ, Cleaver AE, et al. Zinc supplementation during pregnancy: effects on selected blood constituents and on progress and outcome of pregnancy in low income women of Mexican descent. Am $7 \mathrm{Clin}$ Nutr 1984:40.508-21.

\title{
Failure of interferon alfa and tribavirin in rabies encephalitis
}

\author{
M J Warrell, N J White, Sornchai Looareesuwan, R E Phillips, Pravan Suntharasamai, \\ Pornthep Chanthavanich, Mario Riganti, S P Fisher-Hoch, K G Nicholson, Sathaporn Manatsathit, \\ Suparp Vannaphan, D A Warrell
}

Hospital for Tropical Diseases, Faculty of Tropical Medicine, Mahidol University Bangkok, Thailand M J Warrell, MRCPATH, consultant

N J White, FRCP, Wellcome tropical lecturer

Sornchai Looareesuwan, $\mathrm{MD}$, associate professor R E Phillips, FRACP, Wellcome tropical lecturer Pravan Suntharasamai, MD, associate professor

Pornthep Chanthavanich, $\mathrm{MD}$, associate professor Mario Riganti, MD, associate professor of pathology Suparp Vannaphan, BN, head nurse

D A Warrell, FRCP, consultant

Special Pathogens

Laboratory, Centre for

Applied Microbiology and

Research, Public Health

Laboratory Service, Porton

Down, Wiltshire

$S$ P Fisher-Hoch, MD,

Wellcome research fellow

Division of Communicable Diseases, Medical

Research Council, Clinical

Research Centre, Harrow, Middlesex

K G Nicholson, MD, scientific staff

Bamrasnaradura Hospital, Nontaburi, Bangkok,

Thailand

Sathaporn Manatsathit, MRCP, consultant

Correspondence to: Dr.M J Warrell,

John Radcliffe Hospital, Headington, Oxford OX3 9I)U

Br.Med f 1989;299:830-3
Abstract

Objective-To test the effect of interferon alfa and tribavirin (ribavirin) in patients with rabies encephalitis.

Design-An open trial of chemotherapy and intensive care in patients with early rabies.

Setting-The intensive care unit of a Bangkok hospital.

Patients-Four conscious men with clinical rabies encephalitis.

Interventions-Rapid virological diagnosis of rabies. Treatment with intravenous and intraventricular injections of high doses of lymphoblastoid interferon alfa in three patients and tribavirin in one patient. Intensive care was given throughout.

Main outcome measures-Rabies infection confirmed by antigen detection and virus isolation. Rabies neutralising antibody and specific IgM sought in serum and cerebrospinal fluid. Interferon concentrations monitored before and during treatment in three patients.

Results - Interferon alfa treatment produced high concentrations in serum and cerebrospinal fluid. All four patients died after $51 / 2$ to $12 \frac{1}{2}$ days of treatment with no evidence of virostatic or clinically beneficial effects from either treatment.

Conclusion-Interferon alfa treatment is not effective in rabies encephalitis. The use of tribavirin warrants further study, possibly combined with new therapeutic methods.

\section{Introduction}

No records exist of patients surviving furious rabies encephalitis. The three reports of recovery from rabies followed predominantly paralytic illnesses. ${ }^{1-4}$ The diagnosis rested on high concentrations of antibody to the rabies virus in serum and cerebrospinal fluid, but no rabies virus or antigen was detected. Further attempts at intensive care have failed to save patients with rabies. ${ }^{512}$ Clearly, additional therapeutic approaches are necessary.

Interferon prevents replication of the rabies virus in vitro, ${ }^{13-15}$ and a single dose of an interferon inducer given 24 hours after inoculation of the virus protects rabbits against rabies. ${ }^{16}$ Treatment with interferon from human leucocytes affords protection of infected monkeys even if given 11 days after rabies inoculation. Furthermore, interferon treatment has been most effective when given by combined intramuscular and intralumbar routes in monkeys. ${ }^{1-}$ Although endogenous interferon has been detected in some humans with rabies, the concentrations were very low, even in brain tissue sampled at necropsy. ${ }^{18}$ Treatmen with exogenous interferon has been ineffective if used late in the illness ${ }^{1819}$ so we treated patients with early rabies encephalitis with high doses of interferon alfa.

Tribavirin, which selectively blocks the synthesis of viral guanosine nucleotides, is effective against rabies virus, in vitro. ${ }^{2021}$ Protection of mice from rabies by tribavirin treatment has been attempted. A short course of daily injections was given either intramuscularly early or intracerebrally late in the incubation period.". Mortality was not affected, but such brief treatment does not exclude benefit from continuous high concentrations of tribavirin in serum and cerebrospinal fluid. Animal experiments with tribavirin to treat other intracranial viral infections indicate that it does not cross the blood-brain barrier rapidly. ${ }^{23+4}$ This has been confirmed by pharmacokinetic experiments in monkeys (M Ussery, personal communication), though it has been found in the cerebrospinal fluid of patients with AIDS after several weeks of oral treatment. ${ }^{25}$ High doses of intravenous tribavirin have proved effective in Lassa fever in humans. ${ }^{26}$ Tribavirin has not been used intrathecally, but toxicity studies in monkeys showed that five daily injections of $2 \mathrm{mg} / \mathrm{kg}$ by the lumbar route was safe ( $\mathrm{G}$ Ward, unpublished findings). We therefore also investigated the use of tribavirin in rabies encephalitis.

We carried out an open trial of combined intravenous and intrathecal interferon or tribavirin in four fully conscious, cooperative patients with early rabies encephalitis.

\section{Patients and methods}

All patients were admitted to Bamrasnaradura Hospital, Bangkok, and subsequently transferred to the intensive care isolation unit of the Hospital for Tropical Diseases, Bangkok, when the diagnosis of rabies was strongly suspected on the basis of the history and clinical signs. Patients were transferred only with their own fully informed consent and that of their accompanying family. The study was approved by the ethical committees of the Faculty of Tropical Medicine, Mahidol University, and the Thai Ministry of Public Health.

Except in one patient with clinically obvious rabies the diagnosis was confirmed before treatment by detection of rabies antigen around the hair follicles from a skin biopsy specimen with an immunofluorescence test."

When the patients arrived blood and cerebrospinal fluid samples were taken from baseline biochemical, haematological, viral, and drug assays. We inserted an Ommaya reservoir into a lateral cerebral ventricle and a tracheostomy tube under general anaesthesia. A temporary pacemaker was introduced under local 
anaesthesia. Thereafter the patients were managed with barrier nursing and conventional intensive care techniques, bearing in mind the possible side effects of - treatment.

We sought evidence of leakage of protein across the blood-brain barrier by calculating the albumin quotient ${ }^{28}$ and used the IgG index $x^{24}$ to detect intrathecal svnthesis of IgG.

Interferon treatment-Interferon alfa derived from TABLE I - Details of exposure to rabies

\begin{tabular}{cccc}
\hline $\begin{array}{c}\text { Case } \\
\text { No }\end{array}$ & $\begin{array}{c}\text { Age (years), sex } \\
\text { occupation }\end{array}$ & \multicolumn{1}{c}{ Animal contact } & $\begin{array}{c}\text { Incubation } \\
\text { period }\end{array}$ \\
\hline 1 & $54, M$, guard & $\begin{array}{l}\text { Unprovoked dog bite on right big } \\
\text { toe. No vaccine }\end{array}$ & 10 Weeks \\
2 & $27, M$, labourer & $\begin{array}{l}\text { Dog bite on right arm. No vaccine } \\
\text { Dog bite on left leg. No vaccine }\end{array}$ & $\begin{array}{l}3 \text { Months } \\
1 \text { Year }\end{array}$ \\
4 & $14, M$, student & $\begin{array}{l}\text { Caught stray dogs. No definite bite. } \\
2 \text { Nonths }\end{array}$ & 2 , farmer vacine \\
\hline
\end{tabular}

the Namalwa human lymphoblastoid cell line (Wellferon batch $\mathrm{ClN} / 4$, Wellcome Foundation) was given intravenously at a loading dose of $50 \mathrm{MU} / \mathrm{m}^{2}$ body surface infused over six hours. This was repeated over the next 18 hours and then given daily as a continuous intravenous infusion. The intravenous solution was stabilised by the addition of human albumin $1.5 \mathrm{mg} / \mathrm{ml}$ except in the first patient. The first dose of intrathecal interferon was given by the lumbar route, and thereafter it was given into the cerebral ventricle by the Ommaya reservoir. A loading dose of $2 \mathrm{MU} / \mathrm{m}^{2}$ was repeated after six hours and then daily. For the third patient the dose was halved after the first week. Samples of serum and cerebrospinal fluid were stored at $-70^{\circ} \mathrm{C}$ for assay of interferon alfa with a Cell-Tec radioimmunoassay kit.

Tribavirin treatment-Tribavirin (Viratek, United States) was given intravenously as a loading dose of $2 \mathrm{~g}$ ( $30 \mathrm{mg} / \mathrm{kg}$ ) over 20 minutes followed by $1 \mathrm{~g}$ six hourly

TABLE II - Clinical data on four patients with rabies encephalitis
TABLE III - Results of virological tests on four patients with rabies encephalitis

\begin{tabular}{|c|c|c|c|c|c|c|}
\hline \multirow[b]{2}{*}{$\begin{array}{c}\text { Case } \\
\text { No }\end{array}$} & \multirow[b]{2}{*}{$\begin{array}{c}\text { Day of } \\
\text { treatment }\end{array}$} & \multicolumn{3}{|c|}{ Rabies virus } & \multicolumn{2}{|c|}{ Neutralising antibody } \\
\hline & & Specimen & $\begin{array}{c}\text { Antigen } \\
\text { detection }\end{array}$ & $\begin{array}{c}\text { Virus } \\
\text { isolation }\end{array}$ & Serum & $\begin{array}{l}\text { Cerebrospinal } \\
\text { fluid }\end{array}$ \\
\hline \multirow{5}{*}{1} & 1 & Brain & + & + & - & - \\
\hline & 2 & Skin from neck & & & - & - \\
\hline & 3 & Corneal smears & - & & & \\
\hline & 5 & Skin from neck & + & & - & - \\
\hline & 6 & Brain at necropsy & + & + & & \\
\hline \multirow{8}{*}{2} & 1 & Skin from neck & + & & - & - \\
\hline & & Corneal smear & - & & & \\
\hline & & Brain & + & + & & \\
\hline & 5 & & & & - & - \\
\hline & 7 & Corneal smear & - & & & \\
\hline & 8 & & & & - & - \\
\hline & 10 & & & & - & - \\
\hline & 11 & Brain at necropsy & + & + & & \\
\hline \multirow{13}{*}{3} & 1 & Skin from neck & + & & - & - \\
\hline & & Left leg & + & & & \\
\hline & & Right leg & $-t$ & & & \\
\hline & & Brain & - & + & & \\
\hline & & Corneal smears & - & & & \\
\hline & 2 & & & & - & - \\
\hline & 4 & Corneal smears & - & & - & - \\
\hline & 5 & Saliva & & - & & \\
\hline & 6 & Skin from neck & + & & - & - \\
\hline & 8 & & & & + & - \\
\hline & 10 & & & & + & - \\
\hline & 12 & Skin from neck & + & & + & + \\
\hline & & Brain at necropsy & + & + & & \\
\hline \multirow{8}{*}{4} & 1 & Skin from neck & + & & - & - \\
\hline & & Corneal smears & - & & & \\
\hline & & Cerebrospinal fluid & & - & & \\
\hline & & Saliva & & + & & \\
\hline & & Brain & + & + & & \\
\hline & 10 & Skin from leg & + & & - & - \\
\hline & & Skin from neck & + & & & \\
\hline & & Brain at necropsy & + & + & & \\
\hline
\end{tabular}

^Fluorescence antibody test. †No hair follicles in specimen.
(60 mg/kg/dav) for four days and $0.5 \mathrm{~g}$ eight hourly (25 $\mathrm{mg} / \mathrm{kg} / \mathrm{day})$ daily thereafter. Intraventricular tribavirin injections of $100 \mathrm{mg}(2 \mathrm{mg} / \mathrm{kg})$ were given daily through the Ommaya reservoir.

Virological examination-A 4 or $6 \mathrm{~mm}$ punch skin biopsy specimen, corneal smears, and a brain biopsy specimen (taken through the burr hole at insertion of the Ommaya reservoir or at necropsy) were tested for rabies antigen by a fluorescence antibody test." We tried to isolate virus from saliva, cerebrospinal fluid, and brain tissue by inoculating specimens into suckling mice and sometimes also on to cultures of mouse neuroblastoma cells (donated by G M Baer). Rabies neutralising antibody was measured by the rapid immunofluorescence focus inhibition test ${ }^{31}$ and rabies specific IgM by a $\mu$ capture radioimmunoassay test by Dr C H Hoke. ${ }^{32.34}$

\section{Results}

Three patients were treated with interferon and one with tribavirin, but all died between five and 12 davs after starting treatment. Table I shows the nature of their exposure to rabies infection and table II their clinical features.

Virological examination - Table III shows the results of detection and isolation of rabies virus and serological tests. The skin biopsy method of detecting antigen confirmed the diagnosis during life in every case and gave a positive result on admission in three patients. The corneal smear test yielded negative results in all patients on every occasion. The virus was isolated from the brain biopsy specimens taken from all patients during insertion of the Ommaya reservoir, but no 
antigen was detected by the immunofluorescence antibody test in the specimen from the second patient. The needle biopsy brain specimens taken at necropsy contained large amounts of rabies antigen detected by immunofluorescence, and the virus grew readily in suckling mice. The sample from the fourth patient was inoculated on to mouse neuroblastoma cells, and after three days half of the cells were infected, indicating a high virus titre in the brain inoculum. Only the third patient had any detectable rabies antibody (table IV). Neutralising antibody and rabies specific $\operatorname{Ig} M$ appeared during the second week of illness.

TABLE IV - Results of serological tests on third patient

\begin{tabular}{|c|c|c|c|c|}
\hline \multirow[b]{2}{*}{$\begin{array}{c}\text { Day of } \\
\text { treatment }\end{array}$} & \multicolumn{2}{|c|}{ Serum } & \multicolumn{2}{|c|}{ Cerebrospinal fluid } \\
\hline & $\begin{array}{c}\text { Neutralising } \\
\text { antibody }^{\star}\end{array}$ & $\operatorname{IgM} \dagger$ & $\begin{array}{c}\text { Neutralising } \\
\text { antibody }\end{array}$ & $\operatorname{IgM}+$ \\
\hline
\end{tabular}

$\begin{array}{rcccc}1 & - & - & - & - \\ 2 & - & - & - & - \\ 4 & - & - & - & - \\ 6 & - & - & - & - \\ 8 & 0 \cdot 18 & - & - & - \\ 10 & 0.26 & 2 \cdot 1 & - & - \\ 12 & 0.75 & 3 \cdot 1 & 0.31 & -\end{array}$

${ }^{*}$ In IU/ml by rapid immunofluorescence focus inhibition tes †Rabies specific IgM as ratio of positive to negative in $\mu$ capture radioimmunoassay test.

Interferon concentrations-The first and second patients had no detectable interferon $(<62 \mathrm{IU} / \mathrm{ml})$ before treatment, but endogenous interferon $80 \mathrm{IU} / \mathrm{ml}$ was found in the cerebrospinal fluid of the third patient. The figure shows the high interferon concentrations in serum and ventricular cerebrospinal fluid for each patient. The cerebrospinal fluid samples were obtained before treatment and so gave trough concentrations. Table $\mathrm{V}$ shows the ranges of interferon concentrations observed throughout treatment. Accumulation of interferon in the cerebrospinal fluid

TABLE $\mathrm{V}-$ Ranges of interferon alfa concentrations (IU/ml) observed throughout treatment of three patients with rabies encephalitis

\begin{tabular}{cccccc}
\hline & \multicolumn{2}{c}{ Serum } & & \multicolumn{2}{c}{ Cerebrospinal fluid } \\
\cline { 2 - 3 } \cline { 5 - 6 } Case No & Maximum & Minimum & & Maximum & Minimum \\
\hline 1 & 3000 & 840 & & 400000 & 350 \\
2 & 9200 & 200 & & 430000 & $1150 \dagger$ \\
3 & 9600 & 590 & & 350000 & $8550 \dagger$
\end{tabular}

*At least 24 hours after starting treatment.

†Lumbar cerebrospinal fluid specimens, all others ventricular.

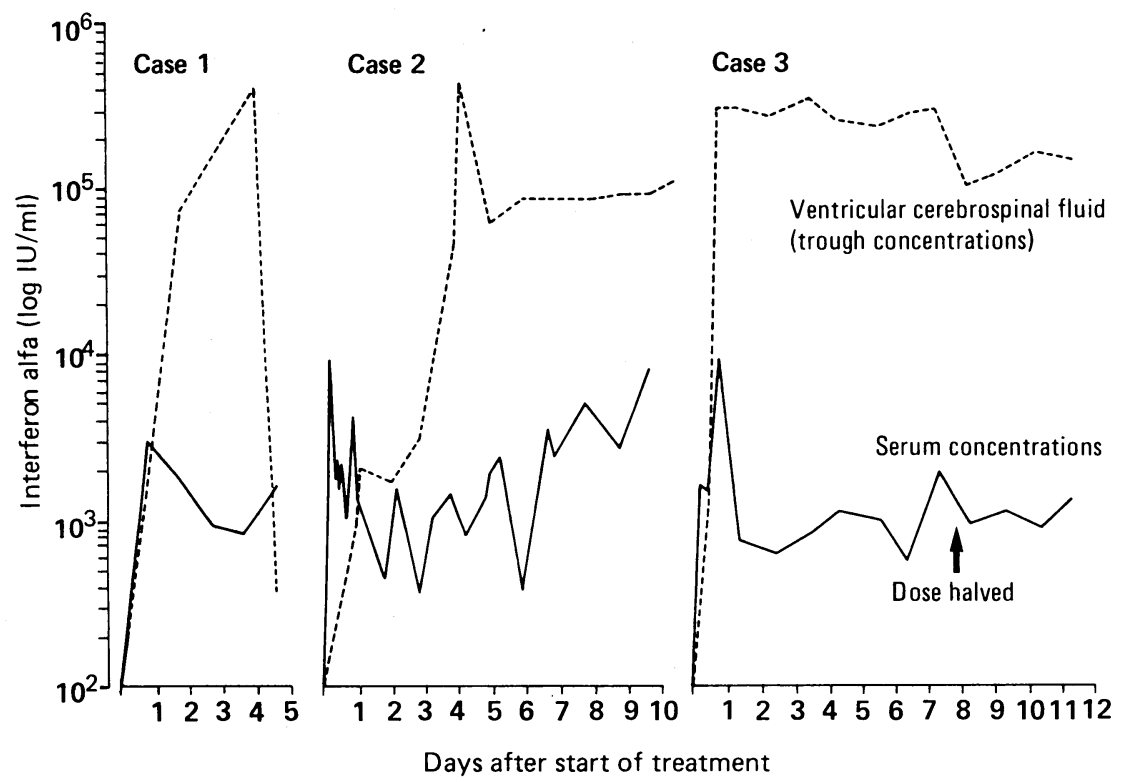

Interferon concentrations in serum and cerebrospinal fluid in three patients with rabies encephalitis was seen in the first two patients so the intrathecal dose was halved after one week for the third patient.

Analysis of cerebrospinal fluid on admission-The changes in the lumbar cerebrospinal fluid were minor. The first and second patients had 20000 and 4000 lymphocytes per litre respectively. No abnormalities in total protein and glucose concentrations were detected, and the IgG indices and albumin quotients were normal, indicating no intrathecal production of IgG or leak across the blood-brain barrier.

Histopathological examination of the cerebral cortex biopsy specimens taken on admission showed only minor, non-specific changes in three cases, but the specimen from the third patient showed Negri bodies and some perivascular mononuclear cell infiltration. In needle biopsy samples taken at necropsy, however, Negri bodies were found in all except the third patient, indicating how focal the pathological changes may be. Perivascular infiltration by mononuclear cells and microglial reaction were often seen, and sparse neuronophagia, demyelination, and petechial haemorrhages were occasionally seen

Haematological and biochemical changes possibly caused by treatment - The first patient had no haematological or biochemical abnormality suggesting interferon toxicity, though the white cell counts of the second and third patients fell to about $3 \times 10^{y} / 1$ in five days but returned to about $10 \times 10^{4} / 1$ before death. The serum potassium concentration of the second patient rose to $9.8 \mathrm{mmol} / \mathrm{l}$ before death, which was associated with creatinine concentrations rising to $630 \mu \mathrm{mol} / \mathrm{l}$, plasma sodium to $156 \mathrm{mmol} / \mathrm{l}$, and blood urea to $22 \mathrm{mmol} / \mathrm{l}$. There was no proteinuria. The serum aspartate aminotransferase activity rose from $53 \mathrm{IU} / 1$ on admission to $268 \mathrm{IU} / \mathrm{l}$ before death, and the bilirubin concentration was $64 \mu \mathrm{mol} / \mathrm{l}$ (direct) or $98 \mu \mathrm{mol} / \mathrm{l}$ (total). The plasma sodium concentration of the third patient also rose from 145 to $161 \mathrm{mmol} / \mathrm{l}$ before death with normal blood urea and potassium concentrations. The serum aspartate aminotransferase activity rose from 28 to $158 \mathrm{IU} / \mathrm{l}$. The only detectable possible side effect of tribavirin treatment in the fourth patient was a fall in haemoglobin concentration from 144 to $107 \mathrm{~g} / \mathrm{l}$ in eight days.

\section{Discussion}

Consistently high concentrations of interferon alfa in the serum and cerebrospinal fluid for several days did not noticeably influence the clinical progression of rabies in three patients. Virus was cultured from brain samples taken at necropsy, and large amounts of rabies antigen were seen by immunofluorescence. There was no evidence that interferon was virostatic in the patients, who started treatment while fully conscious.

A low concentration of endogenous interferon was found in the cerebrospinal fluid of one patient, but experimental evidence suggests that it may have little effect on replication of the rabies virus. An important antiviral action of interferon is stimulation of $2-5 \mathrm{~A}$ synthetase to activate a nuclease, which disrupts viral RNA. The endogenous interferon induced by experimental infection with rabies virus stimulates a form of 2-5A synthetase that is incapable of activating the RNA disrupting nuclease. ${ }^{35}$

Rabies neutralising antibody usually appears within two weeks after the onset of symptoms, ${ }^{12}$ but we found it in only one patient treated with interferon. Merigan et al attributed low rabies antibody concentrations to the immunosuppressive effect of interferon, ${ }^{18}$ which is associated with high interferon concentrations, but interferon treatment in the presence of antigen can increase antibody production experimentally. ${ }^{36}$ Tribavirin is unlikely to have been immunosup-

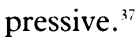


To our knowledge this is the first report of the use of intrathecal tribavirin in humans. No adverse effects were observed. Intravenous tribavirin was given to a patient with rabies in the United States, but treatment was begun in the third week of illness without apparent benefit. ${ }^{38}$ Tribavirin has a virostatic effect in vitro. A concentration of $25 \mu \mathrm{g} / \mathrm{ml}$ inhibits the release of $90 \%$ of infectious virions. ${ }^{20}$ This concentration (equivalent to $10 \mu \mathrm{M}$ tribavirin) would have been attained in the plasma within minutes and lasted at least 12 hours after the initial dose. ${ }^{.9}$ The maintenance of blood concentration is predicted to be well above the inhibitory concentration. Despite nine days' treatment the brain tissue taken at necropsy was full of infectious virus, and so either the drug did not reach the infected cells or it was not virostatic in vivo.

The expected side effects of interferon treatment, lymphopenia and hepatotoxicity, were not serious, but the hyperkalaemia of the second patient was probably fatal. This infrequent complication has been reported by Rohatiner et al $^{+0}$

Rapid confirmation of the diagnosis of rabies is essential if other treatment regimens are to be tried in patients with early signs of encephalitis. We found that antigen detection by immunofluorescence of a skin biopsy specimen was as reliable as an immunofluorescence test on a brain smear at necropsy. ${ }^{3+}$ Blenden et al also advocate this technique. ${ }^{+1}$

In conclusion, the use of interferon alfa or tribavirin alone does not influence the course of rabies encephalitis. The use of these and other compounds such as tungstoantimoniate derivatives ${ }^{21}$ in combination may yet effect a cure. The only treatment that has been effective after the onset of clinical rabies encephalitis is intrathecal vaccination with a live attenuated rabies virus in dogs. ${ }^{+2} \mathrm{~A}$ more attenuated virus, which is apathogenic when injected intrathecally into monkeys, is now available ${ }^{+3}$ and may be used in humans in the future.

At the time of the study MJW worked at Sir William Dunn School of Pathology, University of Oxford. NJW, REP, and DAW are at Nuffield department of clinical medicine, University of Oxford.

The clinical team also included Drs Adisorn Vongsa, Chaisin Viravan, May Ho, Yupaporn Wattanagoon, and George Watt from the Hospital for Tropical Diseases, Bangkok; and Drs Chindra Yongjaiyuth, Somsakdi Chandsri, Somyot Khunjak, and Weera Sinpornchai from Pramonkut Klao Hospital, Bangkok.

We thank the intensive care nurses and diagnostic laboratory staff of the Bangkok Hospital for Tropical Diseases; Emeritus Professor Khunying Tranakchit Harinasuta and Professor Danai Bunnag; Drs Prakorb Bunthai, Santisook Vibulbandhitkii, Sophon Thirachit, and the staff of the rabies ward at the Bamrasnaradura Hospital; technicians Mrs Vanaporn Wuthiekanun and Miss Hilary Wav; Dr C H Hoke and veterinary staff of the American

Forces Research Institute of Medical Sciences; Oxford neuropathologist Dr M Esiri; Dr D Brigden of Wellcome Research Laboratories; Dr H Fernandez of Viratek, ICN Pharmaceuticals; and typist Miss E Berry.

This study was part of the Wellcome-Mahidol University, Oxford Tropical Medicine Research Programme, funded by the Wellcome Trust.

I Hattwick MAW, Weis TT, Stechschulte CJ, Baer GM, Gregg MB. Recovery from rabies. A case report. Ann Intern Med 1972;76:931-42.

2 Porras C, Barboza JJ, Fuenzalida E, Adaros HL, de Diaz AM(), Furst J. Recovery from rabies in man. Ann Intern Med 1976:85:4+-8.

3 Tillotson JR, Axelrod D, Lyman DO Rabies in a laboratory worker-New York. MMWR 1977;26:183-4.

+ Tillotson JR, Axelrod D, Lyman DO. Follow-up on rabies-New York. MMWR 1977;26:249-50.

5 Thiodet J, Fourrier A, Suregeol. Tentatives thèrapeutiques de la rage déclaréc chez. l'homme. Associant les méthodes de réanimation respiratoire, les électro-chocs et la sérotherapie intensive. Survie de 15 et 21 jours. Presse Med 1963;71:172-5.
6 Rubin RH, Sullivan L, Summers R, (iregg MB, Sikes RK. A case of human rabies in Kansas: epidemiologic, clinical and laboratory consudera J Infect Dis 1970:122:318-22.

7 Emmons RW, Leonard LL, DeGenaro F, et al. A case of human rabies with prolonged survival. Intervirology 1973;1:60-72.

8 Bhat DR, Hatwick MAW, Gerdsen R, Emmons RW, Johnson HN. Human rabies diagnosis and management. Am $\mathcal{f}$ Dis Child 1974;127:862-9.

9 Cohen SL, Gardner S, Lanyi C, et al. A case of rabies in man: some problems in diagnosis and management. Br.Med $\mathcal{F} 1976 ; \mathrm{i}: 1041-2$.

10 Maton PN, Pollard JD, Newsom Davis J. Human rabies encephalomyelitis. BrMed f 1976; i: 1038-40

11 Warrell DA, Davidson NMcD, Pope HM, et al. Pathophysiologic studies in human rabies. $A m \mathcal{F}$.Med 1976;60: 180-90.

12 Anderson LJ, Nicholson KG, Tauxe RV, Winkler WG. Human rabies in the United States, 1960 to 1979: epidemiology, diagnosis and prevention. Ann Intern Med 1984;100:728-35.

13 Depoux R, Lepine P. Virus rabique fixe et interferon. Comptes Rendus des Seances de l'Academie des Sciences. Serie III, Sciences de la Vie 1965;260 354-6.

14 Wiktor TJ, Postic B, Ho M, Koprowski H. Role of interferon induction in the prospective activity of rabies vaccines. $\mathcal{F}$ Infect Dis 1972;126:408-18.

15 Atanasiu $P$, Yokota $Y$, Kishida $T$. Interferon and rabies vaccination. Microbiologica 1981;4:301-8.

16 Fenje P, Postic B. Protection of rabbits against experimental rabies by poly poly C. Nature 1970;226:171-2.

17 Weinmann E, Majer M, Hilfenhaus J. Intramuscular and/or intralumba postexposure treatment of rabies virus-infected cynomolgus monkeys with human interferon. Infect Immun 1979;24:24-31.

18 Merigan TC, Baer GM, Winkler WG, et al. Human leukocyte interferon administration to patients with symptomatic and suspected rabies. Ann Neurol 1984;16:82-7.

19 Webster WA, Casey GA, Charlton KM, Sayson RC, McLaughlin B, Noble MA. A case of human rabies in western Canada. Can 7 Public Healt 1987;78:412-3

20 Bussereau F, Chermann J-C, DeClercq E, Hannoun C. Search for compounds which have an inhibitory effect on rhabdovirus multiplication in vitro. Annales de Virologie (Institut Pasteur) 1983;134E:127-34.

21 Bussereau F, Ermine A. Effects of heteropolyanions and nucleoside analogues on rabies virus: in vitro study of synthesis and viral production. Annales de Virologie (Institut Pasteur) 1983;134E:487-506.

22 Bussereau F, Picard $M$, Blancou J, Sureau $\bar{P}$. Treatment of rabies in mice and foxes with antiviral compounds. Acta l'irol (Praha) 1988;32:33-49.

23 Sidwell RW, Allen LB, Khare GP, et al. Effect of 1-p-D-ribofuranosyl-1,2,4 triazole-3-carboxamide (Virazole ICN 1229) on herpes and vaccinia keratitis and encephalitis in laboratory animals. Antimicrob Agents Chemother 1973;3 242-6.

24 Koff W'C, Pratt RD, Elm JL, Venkateshan CN, Halstead SB. Treatment of intracranial dengue virus infections in mice with a lipophilic derivative of ribavirin. Antımicrob Agents Chemother 1983;24:134-6.

25 Crumpcracker C, Bubley G, Lucey D, Hussey S, Connor J. Ribavirin enter the cerebrospinal fluid. Lancet 1986;ii:45-6.

26 McCormick JB, King IJ, Webb PA, et al. Lassa fever: effective therapy with ribavirin. N Engl f Med 1986;314:20-6.

27 Bryceson ADM. Greenwood BM, Warrell DA, et al. Demonstration durin life of rabies antigen in humans. I Infect Dis 1975;131:71-4.

28 Winfield JB Shaw M, Silverman LM, Eisenberg RA, Wilson HA, Koffler D. Intrathecal IgG synthesis and blood-brain barrier impairment in patients with systemic lupus erythematosus and central nervous system dysfunction. A $m$ F Med 1983;74:837-44

29 Thompson EJ, Riches PG, Kohn J. Antibody synthesis within the centr nervous system: comparison of CSF IgG indices and electrophoresis. $f \mathrm{Clin}$ Pathol 1983;36:312-5

30 Dean DJ, Abelseth MK. The fluorescent antibody test. In: Kaplan MM, Koprowski $\mathrm{H}$, eds. Laboratory techniques in rabies. Geneva: World Health Organisation, 1973:73-84

31 Smith JS, Yager PA, Baer GM. A rapid reproducible test for determining rabies neutralizing antibody. Bull WHO 1973;48:535-41.

32 Burke DS, Nisalak A, Ussery MA. Antibody capture immunoassay detection of Japanese encephalitis virus immunoglobulin $\mathrm{M}$ and $\mathrm{G}$ antibodies in of Japanese encephalitis virus immunoglobulin $M$

33 Tingpalapong $\mathrm{M}$. Hoke $\mathrm{CH}$, Ward GS, et al. Anti-rabies virus IgM in serum and cerebrospinal fluid from rabid dogs. Southeast Asian 7 Trop Med Public Health 1986;17:550-7.

34 Warrell MJ, Looareesuwan S, Manatsathit S, et al. Rapid diagnosis of rabies and post-vaccinal encephalitides. Clin Exp Immunol 1988;71:229-34.

35 Hovanessian AG, Marcovistz R, Rivière Y, Guillon JC, Tsiang H. Production and action of interferon in rabies virus infection. In: Smith RA, ed. Interferon treatment of neurologic disorders. New York: M Dekker, 1988: 157-86.

36 Merrill JE, Targan SR. The immunologic basis for the use of interferons. In: Smith RA, ed. Interferon treatment of neurologic disorders. New York: M Dekker, 1988:65-101.

37 Canonico PG. Efficacy, toxicology and clinical applications of ribavirin against virulent RNA viral infections. Antiviral Res 1985;suppl 1:75-81.

38 Swanson D, Feigin R, Tanney L, et al. Human rabies-Texas. MMWR 1984:33:469-70.

39 Laskin OL, Longstreth JA, Hart CC, et al. Ribavirin disposition in high-risk patients for acquired immunodeficiency syndrome. Clin Pharmacol Ther 1987:41:546-55.

40 Rohatiner ZS, Balkwill FR, Griffin DB, Malpas JS, Lister TA. A phase I study of human lymphoblastoid interferon administered by continuous intravenous infusion. Cancer Chemother Pharmacol 1982;9:97-102.

41 Blenden DC, Creech W, Torres-Anjel MJ. Use of immunofluorescence examination to detect rabies virus antigen in the skin of humans with clinical encephalitis. F Infect Dis 1986;154:698-701.

42 Baer GM, Shaddock JH, Williams LW. Prolonging morbidity in rabid dogs by intrathecal injection of attenuated rabies vaccine. Infect Immun 1975;12: 98-103.

43 Warrell MJ, Ward GS, Elwell MR, Tingpalapong M. An attempt to treat rabies encephalitis in monkeys with intrathecal live rabies virus RV675. Arch Virol 1987;96:271-3.

(Accepted 24 fuly 1989) 